\title{
The Brooks-Lindsey Site (41CE293), a Probable Post-A.D. 1650 Caddo Site in the Neches River Basin, Cherokee County, Texas
}

Timothy K. Perttula

Heritage Research Center, Stephen F. Austin State University

Follow this and additional works at: https://scholarworks.sfasu.edu/ita

Part of the American Material Culture Commons, Archaeological Anthropology Commons, Environmental Studies Commons, Other American Studies Commons, Other Arts and Humanities Commons, Other History of Art, Architecture, and Archaeology Commons, and the United States History Commons

Tell us how this article helped you.

This Article is brought to you for free and open access by the Center for Regional Heritage Research at SFA ScholarWorks. It has been accepted for inclusion in Index of Texas Archaeology: Open Access Gray Literature from the Lone Star State by an authorized editor of SFA ScholarWorks. For more information, please contact cdsscholarworks@sfasu.edu. 
The Brooks-Lindsey Site (41CE293), a Probable Post-A.D. 1650 Caddo Site in the Neches River Basin, Cherokee County, Texas

\section{Creative Commons License}

\section{(c) (1) \&}

This work is licensed under a Creative Commons Attribution-NonCommercial 4.0 International License 


\title{
The Brooks-Lindsey Site (41CE293), a Probable Post-A.D. 1650 Caddo Site in the Neches River Basin, Cherokee County, Texas
}

\author{
Timothy K. Perttula
}

\section{INTRODUCTION}

The Brooks-Lindsey site is a probable post-A.D. 1650 Caddo settlement in the Neches River basin in the East Texas Pineywoods (Figure 1). The site was brought to professional archaeological attention in 1986, when collectors who were working the site contacted archaeologists at the Texas Archeological Research Laboratory at The University of Texas at Austin (TARL), and allowed them to examine the ceramic vessel sherd collection they had assembled at that time from surface collections and various excavations.

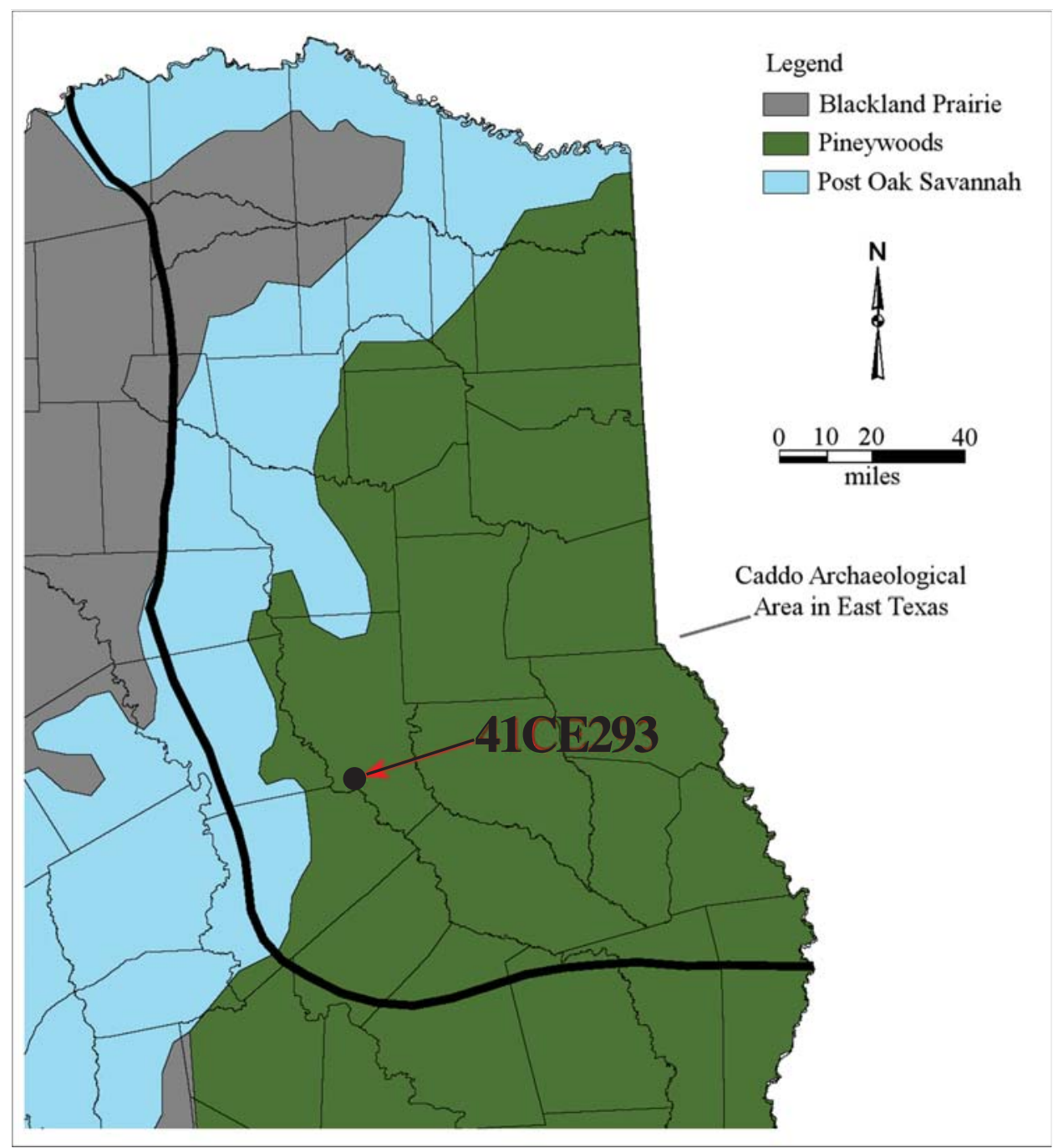

Figure 1. The location of the Brooks-Lindsey site (41CE293) in East Texas. 


\section{SITE CONTEXT}

The site is on a alluvial/colluvial fan in the White Oak Creek valley. White Oak Creek is a southwardflowing tributary to the Neches River, a few miles to the south. The site is estimated to cover a ca. $75 \times 25$ $\mathrm{m}$ area of the landform, and there are midden deposits (a maximum of ca. $90 \mathrm{~cm}$ in depth) at the site that contain high densities of animal bone and ceramic sherds. Not far to the south of the site is a spring-fed drainage that flows west into White Oak Creek. Three ancestral Caddo burials had been exposed north of this drainage, and not far from the midden deposits, some years previously, likely in the early 1930s. One of these burials was reported to have had blue glass beads as funerary offerings, indicating that the BrooksLindsey site may have been occupied after ca. A.D. 1680, when European trade goods began to occur in Neches River basin Caddo sites (see Marceaux 2011).

\section{ARTIFACT ASSEMBLAGE}

More than 560 ceramic sherds were in the Brooks-Lindsey site collection examined by TARL archaeologists in 1986. This included 60 plain sherds and 504 decorated sherds. The plain to decorated sherd ratio is a very low 0.12, indicative of a very late Frankston phase or early Allen phase Caddo occupation (cf. Perttula 2011:Table 6-38). The decorated sherd assemblage is dominated by sherds from utility ware vessels, especially sherds from brushed vessels (Table 1) - about 84 percent of the assemblage of decorated sherds which comprises additional evidence of the mid-to late 17th century age of the midden deposits at the site.

Table 1. Decorated sherd assemblage from the Brooks-Lindsey site (41CE293).

\begin{tabular}{llrr}
\hline Ware & Decorative Method & $\mathrm{N}$ & Percent \\
\hline Utility & & & \\
& Brushed & 423 & 84.0 \\
& Grooved & 27 & 5.4 \\
& Grooved-Punctated & 1 & 0.2 \\
& Incised & 18 & 3.6 \\
& Neck Banded & 2 & 0.4 \\
& Punctated & 21 & 4.2 \\
Fine & & & 2.4 \\
\hline Totals & Engraved & 12 & 100.0 \\
\hline
\end{tabular}

The common occurrence of sherds with grooved decorations further suggests that the Caddo midden deposits date to the late 17 th century A.D. or later. Utility ware jar sherds with grooved decorative elements (i.e., from Lindsey Grooved vessels, see Marceaux 2011) are distributed in two clusters of Caddo sites in the upper Neches and Angelina river basins (Perttula 2015). These sites all date after ca. A.D. 1680 to ca. A.D. 1750 and are historic Caddo sites associated with the Allen phase.

The few engraved sherds are from Poynor Engraved and Patton Engraved vessels. Their co-occurrence in the midden deposits suggest an occupation early in the Allen phase, when both fine wares were apparently being manufactured by upper Neches River Caddo potters (Perttula 2011:286).

In addition to two pipe sherds, a short-stemmed elbow pipe is in the TARL collections from the BrooksLindsey site (Figure 2). The pipe has several rows of small tool punctations on the stem and on the distal 
stem (under the bowl). This is very similar to a punctated elbow pipe from the Fred McKee site (41AN32) in the upper Neches River basin (Perttula 2011:Figure 6-24d). Such pipes, identified as Var. D elbow pipes in Caddo sites in the upper Neches River basin, are present only in post-A.D. 1560 sites, including the latest Frankston phase sites (subphase 3, ca. A.D. 1560-1650) as well as post-A.D. 1650 Allen phase sites at the Emma Owens (41AN21), Fred McKee, E. W. Hackney (41CE6), and Jim P. Allen (41CE12) cemeteries (Perttula 2011:215).

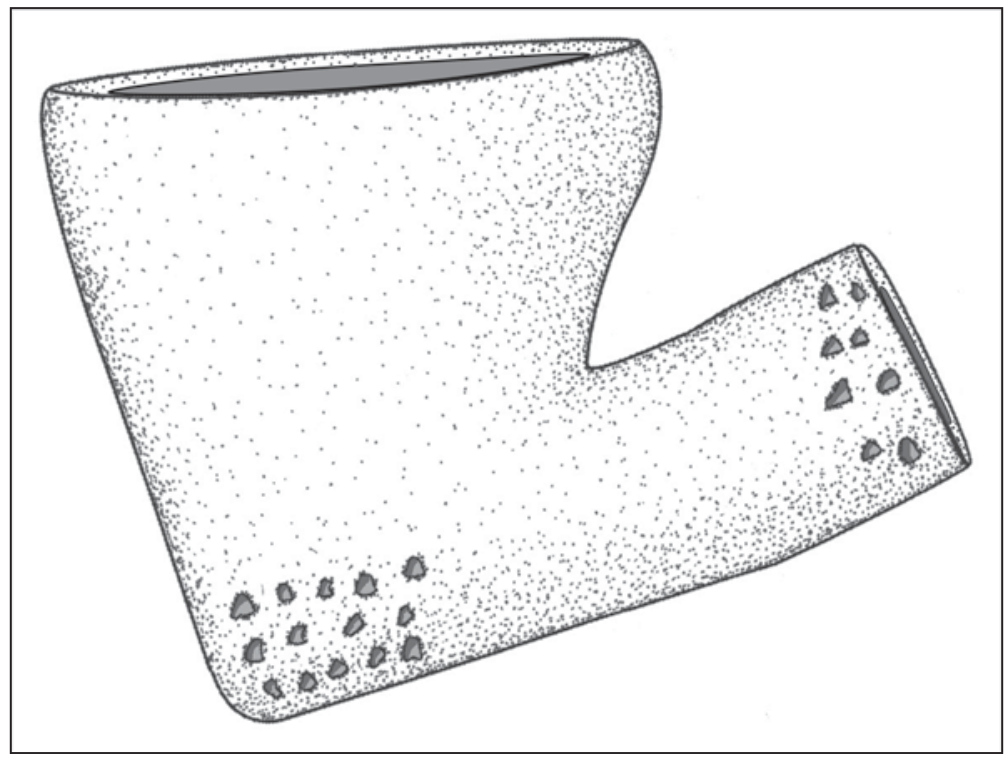

Figure 2. Short-stemmed elbow pipe from the Brooks-Lindsey site.

\section{SUMMARY AND CONCLUSIONS}

The Brooks-Lindsey site (41CE293) is an ancestral Caddo habitation site and possible small cemetery in the White Oak Creek valley in the Neches River basin in East Texas. The site has well-preserved midden deposits not far from an area where three burials had been exposed in the 1930s; one of these burials had blue glass beads as funerary offerings. The site had been investigated by local collectors, who through surface collections and some excavations, had amassed a sizeable collection of sherds from Caddo ceramic vessels as well as a short-stemmed elbow pipe.

The material culture remains from the Brooks-Lindsey site are indicative of a very late Frankston to early Allen phase occupation by Caddo peoples, one that may have taken place from ca. A.D. 1650 to the 1680s. Such an age estimate for the occupation would be consistent with the style of the short-stemmed and punctated elbow pipe reported from the site, the very low $(0.12)$ plain to decorated sherd ratio, the very high proportion of brushed sherds in the assemblage (84 percent of the decorated sherds), and the occurrence of sherds from both Poynor Engraved and Patton Engraved fine ware vessels. Lastly, blue glass beads - as supposedly found with one of the burials at the site-are among the earliest (i.e., late $17^{\text {th }}$ century A.D.) European trade goods found on Allen phase sites in the upper Neches River basin (Cole 1975).

\section{ACKNOWLEDGMENTS}

Lance Trask prepared the figures for this article. 
36 Journal of Northeast Texas Archaeology 55 (2015)

\section{REFERENCES CITED}

Cole, N. M.

1975 Early Historic Caddoan Mortuary Practices in the Upper Neches Drainage, East Texas. Master's thesis, Department of Anthropology, The University of Texas at Austin.

Marceaux, P. S.

2011 The Archaeology and Ethnohistory of the Hasinai Caddo: Material Culture and the Course of European Contact. Ph.D. dissertation, Department of Anthropology, The University of Texas at Austin.

Perttula, T. K.

2011 The Ceramic Artifacts from the Lang Pasture Site (41AN38) and the Place of the Site within an Upper Neches River Basin Caddo Ceramic Tradition. In Archeological Investigations at the Lang Pasture Site (41AN38) in the Upper Neches River Basin of East Texas, assembled and edited by T. K. Perttula, D. B. Kelley, and R. A. Ricklis, pp. 145-320. Archeological Studies Program Report No. 129, Texas Department of Transportation, Environmental Affairs Division, Austin.

2015 East Texas Caddo Ceramic Sherd Database. Journal of Northeast Texas Archaeology 51:1-46. 